\title{
Larvicidal potentiality, longevity and fecundity inhibitory activities of Bacillus sphaericus (Bs G3-IV) on vector mosquitoes, Aedes aegypti and Culex quinquefasciatus
}

\author{
A. Nareshkumar, ${ }^{1}$ K. Murugan, ${ }^{1}$ I. Baruah, ${ }^{2}$ P. Madhiyazhagan, ${ }^{1}$ T. Nataraj ${ }^{1}$ \\ ${ }^{1}$ Department of Zoology, Bharathiar University, Coimbatore; ${ }^{2}$ Defence Research and Development \\ Organization, Defence Research Laboratory, Assam, India
}

\begin{abstract}
Intervention measures to control the transmission of vector-borne diseases include control of the vector population. In mosquito control, synthetic insecticides used against both the larvae (larvicides) and adults (adulticides) create numerous problems, such as environmental pollution, insecticide resistance and toxic hazards to humans. In the present study, a bacterial pesticide, Bacillus sphaericus (Bs G3-IV), was used to control the dengue and filarial vectors, Aedes aegypti and Culex quinquefasciatus. Bacillus sphaericus (Bs G3-IV) was very effective against Aedes aegypti and Culex quinquefasciatus, showing significant larval mortality. Evaluated lethal concentrations $\left(\mathrm{LC}_{50}\right.$ and $\left.\mathrm{LC}_{90}\right)$ were age-dependent, with early instars requiring a lower concentration compared with later stages of mosquitoes. Culex quinquefasciatus was more susceptible to Bacillus sphaericus (Bs G3-IV) than was Aedes aegypti. Fecundity rate was highly reduced after treatment with different concentrations of Bacillus sphaericus (Bs G3-IV). Larval and pupal longevity both decreased after treatment with Bacillus sphaericus (Bs G3-IV), total number of days was lower in the B. sphaericus treatments
\end{abstract}

Correspondence: Kadarkarai Murugan, Department of Zoology, Bharathiar University, Coimbatore, 641046, India. E-mail: kmvvkg@gmail.com

Key words: Bacillus sphaericus (Bs G3-IV), Aedes aegypti, Culex quinquefasciatus, fecundity, mosquito longevity.

Acknowledgments: we are very thankful to the authorities of the Defence Research and Development Laboratory (DRDL), Defence Research and Development Organization, Ministry of Defence, Government of India, Tezpur for providing funds plus their isolate of Bacillus sphaericus, for the successful completion of this project.

Received for publication: 20 August 2012.

Revision received: 20 November 2012.

Accepted for publication: 20 November 2012.

(C) Copyright A. Nareshkumar et al., 2012

Licensee PAGEPress, Italy

Journal of Entomological and Acarological Research 2012; 44:e15

doi:10.4081/jear.2012.e15

This article is distributed under the terms of the Creative Commons Attribution Noncommercial License (by-nc 3.0) which permits any noncommercial use, distribution, and reproduction in any medium, provided the original author(s) and source are credited. compared with the control. Our results show the bacterial pesticide Bacillus sphaericus (Bs G3-IV) to be an effective mosquito control agent that can be used for more integrated pest management programs.

\section{Introduction}

Mosquitoes are insect vectors responsible for the transmission of many diseases. Mosquito-borne diseases include yellow fever, dengue fever and Chikungunya, transmitted mostly by Aedes aegypti; malaria, carried by the genus Anopheles, and Culex serves as a vector of important diseases such as West Nile virus, filariasis, Japanese encephalitis, St. Louis encephalitis, and avian malaria. Insect-transmitted disease remains a major source of illness and death worldwide. Mosquitoes alone transmit disease to more than 700 million people annually and are responsible for several million deaths every year (WHO, 2012; Taubes, 2000; Kessler \& Guerin, 2008).

Management of these vectors is a serious concern in a developing country like India, due to development of pesticide resistance and for socio-economic reasons. Every year, a large part of the population is affected by one or more vector-borne diseases. Vector control, which includes both anti-larval and anti-adult measures, constitutes an important aspect of any mosquito control program. Mosquito control using synthetic insecticides is an effective vector control strategy used extensively in daily life. Synthetic insecticides are still at the forefront of mosquito-controlling efforts. However, the environmental threat that these chemicals pose affects on non-target organisms, and resistance of mosquitoes to insecticides have all increased during the last five decades (Wattanachai \& Tintanon, 1999; Amer \& Mehlhorn, 2006a, 2006b).

In recognition of these facts, it is necessary to develop new insecticides for controlling mosquitoes that are environmentally safer, biodegradable, and more target-specific against the mosquitoes. Recent negative consumer perceptions concerning the use of chemicals as larvicides have shifted research efforts towards the development of alternatives that the public perceives as natural products, such as bacterial pesticides, predators, and plant extracts. Consequently, the present work deals with the insecticidal activities of natural products, such as bacterial pesticides.

Bacillus sphaericus is an aerobic, mesophilic, spore-forming bacterium with terminal swollen sporangia and spherical spores. As a consequence of the specific toxicity to mosquito larvae of binary toxin (Bin) and mosquitocidal toxins (Mtxs) produced during the sporulation and vegetative stages, respectively, some toxic strains have been widely used for many years as biopesticides in the field in mosquito control programs (Bei et al., 2007).

Bacillus sphaericus is a naturally occurring soil bacterium that can 
effectively kill mosquito larvae present in water. $B$. sphaericus has the unique property of being able to control mosquito larvae in water that is rich in organic matter. Depending on the formulation and environmental conditions, $B$. sphaericus is generally effective 1-4 weeks after application (Charles et al., 1996). The larvicidal binary toxin produced by $B$. sphaericus is composed of two chains, BinA ( $42 \mathrm{kDa})$ and BinB $(51 \mathrm{kDa})$ that are deposited as parasporal crystals during sporulation (Baumann et al., 1991). These crystals bind to a specific receptor present on midgut brush-border membranes, resulting in damage to the midgut cells, which further leads to the mosquito's death (NeilsenLeroux \& Charles, 1992).

Bacillus sphaericus is specific and toxic against the genera Culex and Anopheles. It is harmless to humans, animals and the environment, and its use is recommended by the World Health Organization in public health programs worldwide (WHO, 1987). Many strains of $B$. sphaericus have been used as a toxicant in vector control programs all over the world (Regis et al., 2001). In a recent study in Brazil, da Silva Pinto et al. (2012) cloned the BinA and BinB genes of Bacillus sphaericus, produced recombinant BinAB protein in three strains of Escherichia coli, and used these recombinant strains in toxicity assays against Culex quinquefasciatus larvae.

Research on Bacillus sphaericus in South Asian countries and India includes a number of strains, such as Bacillus sphaericus strain SI-1 (Hossain et al., 2007), Bacillus sphaericus strain B-101 (serotype H5a, 5b) (Yadav et al., 1997), Bacillus sphaericus H5a5b (VCRC B42) (Prabhakaran et al., 2007), Bacillus sphaericus $\mathrm{H}-5 \mathrm{a} 5 \mathrm{~b}$ (Manonmani \& Hoti, 1999), Bacillus sphaericus (Bs) 2362 SPH-88 (serotype: H5a5b) (Poopathi et al., 2009), Bacillus sphaericus, C3-41, 2362, and IAB59 (Pei et al., 2002) for mosquito control. Mosquito larvicidal activity of $B$. sphaericus was assessed by isolating it from ecologically different soil habitats in South India (Surendran \& Vennison, 2011).

The present study was conducted to test the larvicidal and pupacidal activities of the microbial insecticide Bacillus sphaericus (Bs G3-IV) on Aedes aegypti and Culex quinquefasciatus in the laboratory as well as in direct breeding sites. We also report the effects of Bacillus sphaericus (Bs G3-IV) on longevity and fecundity of Aedes aegypti and Culex quinquefasciatus.

\section{Materials and methods}

\section{Collection of eggs and mosquitoes}

Eggs of Aedes aegypti were collected using oviposition traps placed in shaded areas at a height of less than $1.2 \mathrm{~m}$. Traps were filled with water plus a few dried leaves placed at the bottom of the container, with a muslin strip placed vertically inside the container and half-submerged in the water. Culex quinquefasciatus egg rafts were collected from sewage water bodies in Coimbatore district, Tamil Nadu, India, using CDC gravid traps (Reiter 1983, 1987). These eggs were brought to the laboratory and transferred to $18 \times 13 \times 4 \mathrm{~cm}$ enamel trays (with separate trays for each species) containing $500 \mathrm{~mL}$ of water, and held for larval hatch.

\section{Maintenance of larvae}

The mosquito larval culture was maintained in our laboratory at $27+2^{\circ} \mathrm{C}, 75-85 \% \mathrm{RH}$. The mosquito larvae were fed with dog biscuits and yeast (Scottlabs Pvt. Ltd., Hyderabad, India) at a 3:1 ratio. The feeding was continued until the larvae transformed into pupae.

\section{Maintenance of pupae and adults}

The pupae were collected from the culture trays and transferred into plastic jar containers $(12 \times 12 \mathrm{~cm})$ containing $500 \mathrm{~mL}$ of water. These plastic jars were kept in a $90 \times 90 \times 90 \mathrm{~cm}$ mosquito cage for adult emer- gence. The emerged adults were maintained at $27 \pm 2^{\circ} \mathrm{C}, 75-85 \% \mathrm{RH}$, under 14 light (L):10 dark (D) photoperiod cycles. Adults were fed with $10 \%$ sugar solution for a period of three days before they were given an animal for blood feeding.

\section{Blood feeding of adult mosquitoes}

The female mosquitoes were allowed to feed on the blood of a rabbit (exposed on the dorsal side) for two days. The males were provided with $10 \%$ glucose solution on cotton wicks. The cotton was kept moist with the solution and changed every day. An egg trap (cup) lined with filter paper containing water was placed in a corner of the egg collection cage.

\section{Collection and preparation of Bacillus sphaericus}

Bacillus sphaericus (Bs G3-IV) with improved toxicity was collected from Defence Research Laboratory, Tezpur, Assam, India. To assure good suspensions for selection and bioassay procedures, stock suspensions $(1 \mathrm{ppm})$ of the primary powders were prepared in distilled water by vigorously shaking $1 \mathrm{~g}$ of the powder in $1000 \mathrm{~mL}$ of water in a screwcap glass vial. Required concentrations $(0.001 \mathrm{ppm}, 0.01 \mathrm{ppm}, 0.1 \mathrm{ppm}$, $1.0 \mathrm{ppm}$, and $10 \mathrm{ppm}$ ) were prepared by serial dilution of the stock solution in distilled water. All stocks and dilutions were kept refrigerated at $-4^{\circ} \mathrm{C}$ for no more than four months.

\section{Larval/pupal assays}

Laboratory colonies of mosquito larvae/pupae (F1 generation) were used for the larvicida/pupacidal activity. Twenty-five individual I-IVinstar larvae and pupae were introduced into a $500 \mathrm{~mL}$ glass beaker containing $250 \mathrm{~mL}$ of dechlorinated water with the desired concentrations of biopesticide. Larval food was provided for the test larvae. At each tested concentration, 2-5 trials were run and each trial consisted of 3 replicates. The larvae/pupae exposed to dechlorinated water without biopesticide served as a control. The control mortalities were corrected using Abbott's formula (Abbott, 1925) where:

$$
\begin{gathered}
\begin{array}{c}
\text { Corrected } \\
\text { mortality }
\end{array}=\frac{\text { Observed mortality in treatment }- \text { Observed mortality in control }}{100-\text { Control mortality }} \times 100 \\
\text { Percent mortality }=\frac{\text { Number of dead larvae/pupae }}{\text { Number of larvae/pupae introduced }} \times 100
\end{gathered}
$$

\section{Fecundity studies}

The fecundity experiments were conducted by taking an equal number of male and female mosquito larvae that had emerged from the control and treated sets. These were placed in individual $30 \times 30 \mathrm{~cm}$ cages for each concentration. Three days after the blood meal, eggs were collected daily from small plastic bowls containing water kept in an ovitrap in the cages. Fecundity was calculated from the number of eggs laid in ovitraps divided by the number of mated females. Death of adults in these experiments was taken into account.

\section{Longevity test}

The adult longevity of male and female mosquitoes (F1 generation) was also recorded. This was calculated as the number of days lived by the adult. Total number of days from adult emergence to death was recorded and the means were calculated to give the mean longevity in days.

\section{Field trial}

Field applications of plant extracts were made uniformly with a knapsack sprayer on the surface of the water in each habitat. Sampling of larvae was undertaken before treatment and 24, 48, 72 and $96 \mathrm{~h}$ after treatment by dipper sampling and counting. A separate sample was taken to determine the species composition of each larval habitat. Six trials were conducted for each area with similar temperature and alti- 
tude. The required quantity of biopesticide was determined by calculating the total surface area, and the required concentration was prepared by multiplying ten times the observed laboratory $\mathrm{LC}_{50}$ values. Percent reduction of the larval density was calculated using the formula:

$$
\text { Percent reduction }=\frac{C-T}{T} \times 100
$$

where

$\mathrm{C}$ - total number of mosquitoes in control

$\mathrm{T}$ - total number of mosquitoes in treatment

\section{Statistical analysis}

The data obtained from the bioassay were subjected to statistical analysis using SPSS (Version 14.0) software (IBM Corp., Armonk, NY, USA). Lethal concentrations (LC), LC50 and LC90, DMRT (Duncan Multiple Range Test) and $\chi^{2}$ tests were used.

\section{Results}

Table 1 illustrates the larval (I-IV) and pupal mortality data of the dengue vector, Aedes aegypti, after treatment with Bacillus sphaericus (Bs G3-IV) at different concentrations. The maximum mortality observed was $100 \%$ at $10 \mathrm{ppm}$ concentration in I and II instar larvae. The observed mortality rate was greatly reduced in late instar larvae and pupae. Pupae showed high resistance to Bacillus sphaericus (Bs G3-IV), with low mortality rates of $2 \%, 2 \%, 3 \%, 12 \%$ and $30 \%$ at $0.001 \mathrm{ppm}, 0.01 \mathrm{ppm}, 0.1 \mathrm{ppm}$, 1.0 ppm and 10 ppm, respectively. Duncan's Multiple Range Test proved that the observed mortality rates were significant at $\mathrm{P}<0.05$. $\mathrm{LC}_{50}$ values for I, II, III and IV instar larvae were $0.60 \mathrm{ppm}, 0.72 \mathrm{ppm}, 2.45 \mathrm{ppm}$ and $3.76 \mathrm{ppm}$, respectively, and, for pupae, $14.08 \mathrm{ppm}$.

Percentages of larval and pupal mortality of the filarial vector, Culex quinquefasciatus, after treatment with Bacillus sphaericus (Bs G3-IV) at different concentrations $(0.001 \mathrm{ppm}, 0.01 \mathrm{ppm}, 0.1 \mathrm{ppm}, 1.0 \mathrm{ppm}$ and $10 \mathrm{ppm}$ ) are shown in Table 2 . Mortality values ranged from $22 \%$ to $100 \%$ for the larval stages, but were greatly reduced for the pupal stage. At the highest concentration (10 ppm), no larvae were found alive and $100 \%$ mortality was recorded. Duncan's Multiple Range Test proved that the observed mortality rates were significant at $\mathrm{P}<0.05$. The calculated $\mathrm{LC}_{50}$ and $\mathrm{LC}_{90}$ values are $0.07 \mathrm{ppm}$ and $0.56 \mathrm{ppm}, 0.15 \mathrm{ppm}$ and $0.87 \mathrm{ppm}$, $0.29 \mathrm{ppm}$ and $1.14 \mathrm{ppm}, 0.41 \mathrm{ppm}$ and $1.32 \mathrm{ppm}$, and $10.84 \mathrm{ppm}$ and $25.14 \mathrm{ppm}$ for I, II, III, IV instar larvae and pupae, respectively.

Adult longevity and fecundity of the dengue vector, Aedes aegypti, after treatment with Bacillus sphaericus (Bs G3-IV) is shown in Table 3. A significant reduction in adult longevity and fecundity was recorded in this experiment when compared with the control. Longevity and fecundity after treatment with different concentrations of Bacillus

Table 1. Larvicidal and pupacidal activity of Bacillus sphaericus on the dengue vector, Aedes aegypti.

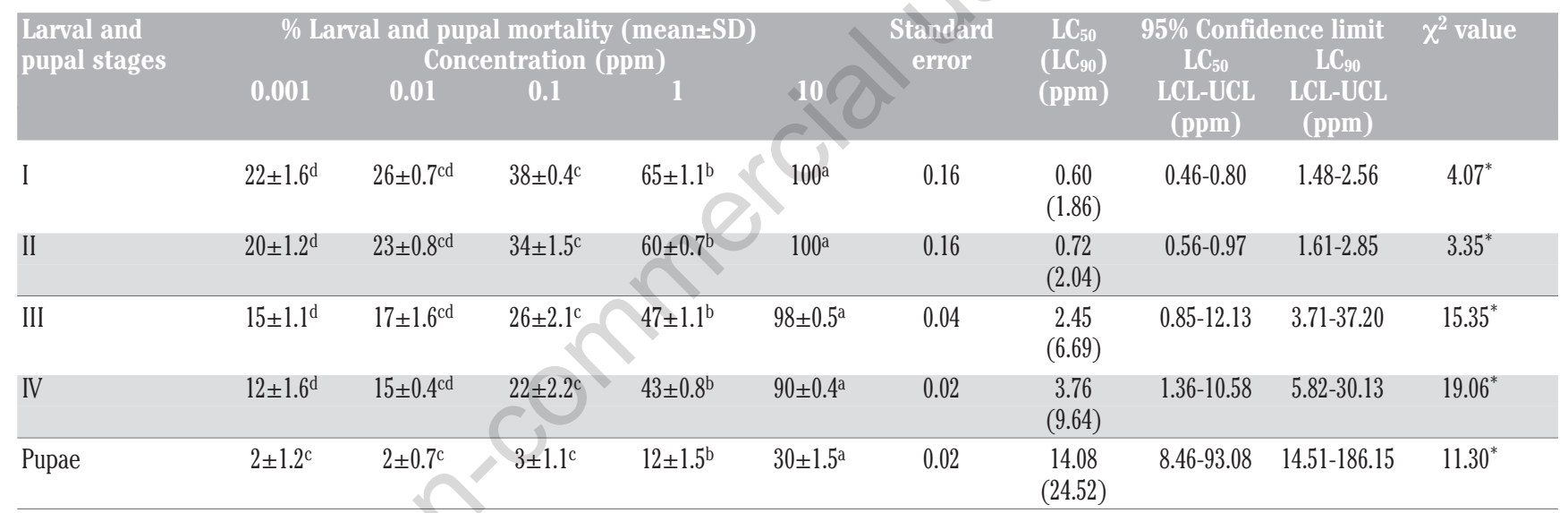

Means \pm standard deviation (SD) followed by same letter within rows indicate no significant difference (Duncan's multiple range test, $\mathrm{P}<0.05$ ). $\mathrm{LC} \mathrm{C}_{50}$, $\mathrm{LC} \mathrm{C}_{90}$, lethal concentration; $\mathrm{LCL}$, lower confidence limits; UCL, upper confidence limits. ${ }^{*}$ Significant at $\mathrm{P}<0.001$ (heterogeneity factor used in calculation of confidence limits).

Table 2. Larvicidal and pupacidal activity of Bacillus sphaericus on the filarial vector Culex quinquefasciatus.

\begin{tabular}{|c|c|c|c|c|c|c|c|c|c|c|}
\hline \multirow[t]{2}{*}{$\begin{array}{l}\text { Larval and } \\
\text { pupal stages }\end{array}$} & \multicolumn{5}{|c|}{$\begin{array}{c}\text { \% Larval and pupal mortality (mean } \pm \text { SD) } \\
\text { Concentration (ppm) }\end{array}$} & \multirow[t]{2}{*}{$\begin{array}{l}\text { Standard } \\
\text { error }\end{array}$} & \multirow{2}{*}{$\begin{array}{l}\mathrm{LC}_{50} \\
\left(\mathrm{LC} \mathrm{C}_{90}\right) \\
(\mathrm{ppm})\end{array}$} & \multirow{2}{*}{\multicolumn{2}{|c|}{$\begin{array}{cc}95 \% \text { Confidence limit } \\
\text { LC }_{50} & \text { LC }_{90} \\
\text { LCL-UCL } & \text { LCL-UCL } \\
(\mathrm{ppm}) & (\mathrm{ppm})\end{array}$}} & \multirow[t]{2}{*}{$\chi^{2}$ value } \\
\hline & 0.001 & 0.01 & 0.1 & 1 & 10 & & & & & \\
\hline I & $38 \pm 0.4^{\mathrm{cd}}$ & $43 \pm 1.1^{\mathrm{c}}$ & $58 \pm 0.7^{\mathrm{b}}$ & $99 \pm 0.4^{\mathrm{a}}$ & $100^{\mathrm{a}}$ & 0.42 & $\begin{array}{c}0.07 \\
(0.56)\end{array}$ & $0.02-0.13$ & $0.43-0.79$ & $2.00^{*}$ \\
\hline II & $35 \pm 0.9$ cd & $39 \pm 1.6^{\mathrm{c}}$ & $53 \pm 2.1^{\mathrm{b}}$ & $93 \pm 0.5^{\mathrm{ab}}$ & $100^{\mathrm{a}}$ & 0.21 & $\begin{array}{c}0.15 \\
(0.87)\end{array}$ & $0.07-0.23$ & $0.72-1.10$ & $2.68^{*}$ \\
\hline III & $27 \pm 1.2^{\mathrm{de}}$ & $32 \pm 0.7^{\mathrm{d}}$ & $48 \pm 1.2^{c}$ & $85 \pm 1.2^{b}$ & $100^{\mathrm{a}}$ & 0.18 & $\begin{array}{c}0.29 \\
(1.14)\end{array}$ & $0.08-0.54$ & $0.79-2.13$ & $5.49^{*}$ \\
\hline IV & $22 \pm 0.9^{\text {de }}$ & $28 \pm 1.1^{\mathrm{d}}$ & $42 \pm 2.2^{c}$ & $79 \pm 0.9^{b}$ & $100^{\mathrm{a}}$ & 0.17 & $\begin{array}{c}0.41 \\
(1.32)\end{array}$ & $0.19-0.72$ & $0.92-2.48$ & $5.48^{*}$ \\
\hline Pupae & $11 \pm 1.5^{\mathrm{d}}$ & $13 \pm 0.5^{\mathrm{cd}}$ & $18 \pm 0.6^{c}$ & $28 \pm 1.6^{b}$ & $46 \pm 1.5^{\mathrm{a}}$ & 0.02 & $\begin{array}{c}10.84 \\
(25.14)\end{array}$ & $6.01-90.25$ & $14.15-243.62$ & $8.72^{*}$ \\
\hline
\end{tabular}

Means \pm standard deviation (SD) followed by same letter within rows indicate no significant difference (Duncan's multiple range test, $\mathrm{P}<0.05$ ). $\mathrm{LC} \mathrm{C}_{50}$, $\mathrm{LC} \mathrm{C}_{90}$, lethal concentration; $\mathrm{LCL}$, lower confidence limits; UCL, upper confidence limits. ${ }^{*}$ Significant at $\mathrm{P}<0.001$ (heterogeneity factor used in calculation of confidence limits). 
sphaericus (Bs G3-IV) were 26.4 days (d) in males and $37.9 \mathrm{~d}$ in females at $0.001 \mathrm{ppm}$ concentration, $21.8 \mathrm{~d}$ in males and $35.7 \mathrm{~d}$ in females at $0.01 \mathrm{ppm}$ concentration, $18.9 \mathrm{~d}$ in males and $31.2 \mathrm{~d}$ in females at 0.1 ppm concentration, $15.8 \mathrm{~d}$ in males and $27.3 \mathrm{~d}$ in females at $1.0 \mathrm{ppm}$ concentration, and $11.6 \mathrm{~d}$ in males and $21.1 \mathrm{~d}$ in females at $10 \mathrm{ppm}$ concentration. Fecundity was also reduced after treatment with Bacillus sphaericus (Bs G3-IV). A total of 178 eggs were recorded in the control, and the number of eggs recorded in the $B$. sphaericus treatments were $170,155,137,116$ and 82 at $0.001 \mathrm{ppm}, 0.01 \mathrm{ppm}, 0.1 \mathrm{ppm}, 1.0 \mathrm{ppm}$ and $10 \mathrm{ppm}$, respectively.

Adult longevity and fecundity of the filarial vector, Culex quinquefasciatus, after treatment with Bacillus sphaericus (Bs G3-IV) is shown in Table 4. Significant reduction in adult longevity and fecundity was recorded compared with the control. Longevity and fecundity recorded after treatment with different concentrations of Bacillus sphaericus (Bs G3-IV) were $30.9 \mathrm{~d}$ in males and $44.1 \mathrm{~d}$ in females at $0.001 \mathrm{ppm}$ concentration, $25.8 \mathrm{~d}$ in males and $38.4 \mathrm{~d}$ in females at $0.01 \mathrm{ppm}$ concentration, $18.2 \mathrm{~d}$ in males and $25.9 \mathrm{~d}$ in females at $0.1 \mathrm{ppm}$ concentration, $11.8 \mathrm{~d}$ in males and $14.6 \mathrm{~d}$ in females at $1.0 \mathrm{ppm}$ concentration, and 4.7 $\mathrm{d}$ in males and $7.1 \mathrm{~d}$ in females at $10 \mathrm{ppm}$ concentration. The fecundity was also highly reduced after treatment with Bacillus sphaericus (Bs G3-IV). A total of 270 eggs were recorded in the control, compared with $249,215,178,119$ and 63 at $0.001 \mathrm{ppm}, 0.01 \mathrm{ppm}, 0.1 \mathrm{ppm}, 1.0 \mathrm{ppm}$ and $10 \mathrm{ppm}$, respectively, of $B$. sphaericus.

Table 5 shows the effect of Bacillus sphaericus (Bs G3-IV) on the dengue vector, Aedes aegypti, in their breeding sites. The field trial was conducted in stagnant water bodies at Vadavalli. The surface areas of the selected breeding sites were $0.6 \times 0.7 \times 0.5 \mathrm{~m}$. A total of 481 larvae were found. After treatment with Bacillus sphaericus (Bs G3-IV), the percentage of reduction in larval density was $39.70 \%, 59.87 \%, 82.74 \%$ and $96.25 \%$ at $24 \mathrm{~h}, 48 \mathrm{~h}, 72 \mathrm{~h}$ and $96 \mathrm{~h}$, respectively.

Field application of Bacillus sphaericus (Bs G3-IV) in the sewage water systems in Vadavalli (breeding sites of the filarial vector, Culex quinquefasciatus), is given in Table 6 . The surface areas of the selected breeding sites were $0.4 \times 1.7 \times 0.28 \mathrm{~m}$. Required quantity and concentration of biopesticide were calculated as $0.19 \mathrm{~L}$ and $2.88 \mathrm{ppm}$, respectively. A total of 788 larvae were found. After treatment with Bacillus sphaericus (Bs G3-IV), the percentage of reduction in larval density was $65.1 \%$, $87.6 \%, 97.5 \%$ and $100 \%$ at $24 \mathrm{~h}, 48 \mathrm{~h}, 72 \mathrm{~h}$ and $96 \mathrm{~h}$, respectively.

\section{Discussion}

Mosquitoes breed in varied habitats, such as ponds, marshes, ditches, pools, drains, water containers and other similar collections of water (Rozendaal, 1997). Mosquitoes such as Anopheles, Culex and Aedes are vectors responsible for diseases such as malaria, filariasis, Japanese encephalitis, dengue, dengue hemorrhagic fever, yellow fever and chikungunya. The increase in mosquito vectors and incidence of mosquito-borne diseases such as malaria, dengue, and chikungunya is rising in India due to climate change and water contamination. Unclean water bodies act as temporary and permanent breeding sites of mosquitoes, which tend to spread mosquito-borne diseases, along with cholera, dysentery, typhoid, etc.

Understanding the ecology of mosquitoes and the mechanism of disease management is a prerequisite to adopting any type of control. In general, the population of vector species must be of sufficient size so as to promote the transmission of vector-borne diseases. If the vector population falls below a critical density, the transmission of these diseases will not be very effective.

Effective mosquito control is often a complex, expensive task, frequently requiring the cooperative efforts of communities as well as industry, agriculture, and state and local governments. We must be con- cerned with the harmful effects of synthetic pesticides on the environment and living organisms, and reports have emerged on the resurgence of several mosquito-borne diseases in the world as a consequence of increasing resistance of mosquitoes to commercial insecticides (Becker et al., 2003). This has necessitated the need for research and development of environmentally safe, biodegradable, indigenous methods for vector control.

We found Bacillus sphaericus (Bs G3-IV) to be significantly effective against Aedes aegypti and Culex quinquefasciatus. This may have been due to the presence of binary toxin (Bin) and mosquitocidal toxins (Mtxs). The Bin toxin produced by Bacillus sphaericus targets mosquito larval midgut epithelial cells, where it binds to Cpml (Culex pipiens maltase 1), a digestive enzyme, and causes severe intracellular damage, including dramatic cytoplasmic vacuolation (Opota et al., 2011). Culex quinquefasciatus was much more susceptible to Bacillus sphaericus (Bs G3-IV), showing $100 \%$ mortality at a $10 \mathrm{ppm}$ concentration against I-IV instars. Median lethal concentrations (LC50) observed were relatively low (0.07 ppm, 0.15 ppm, 0.29 ppm, 0.41 ppm, and $10.84 \mathrm{ppm}$ for I, II, III, IV instar larvae and pupae, respectively) when compared with Aedes aegypti. Earlier, Yousten and Davidson (1982) and Davidson (1983) reported that Bacillus sphaericus, a spore-forming, entamopathogenic bacterium, possess potent larvicidal activity against several species of mosquito larvae. As a consequence of the specific toxicity to mosquito larvae of binary toxin (Bin) and mosquitocidal toxins (Mtxs) produced during the sporulation and vegetative stages, respectively, some toxic strains have been widely used for many years as biopesticides in the field in mosquito control programs (Bei et al., 2007).

Table 3. Effect of Bacillus sphaericus on fecundity and longevity of dengue vector Aedes aegypti in the laboratory.

\begin{tabular}{lccc}
$\begin{array}{l}\text { Treatment } \\
(\mathrm{ppm})\end{array}$ & \multicolumn{2}{c}{$\begin{array}{c}\text { Adult longevity } \\
\text { (Ins) }\end{array}$} & Fecundity \\
& Male & Female & \\
Control & $29 \pm 0.2^{\mathrm{a}}$ & $39 \pm 0.5^{\mathrm{a}}$ & $178 \pm 0.4^{\mathrm{a}}$ \\
0.001 & $26.4 \pm 0.9^{\mathrm{b}}$ & $37.9 \pm 0.6^{\mathrm{ab}}$ & $170 \pm 1.6^{\mathrm{ab}}$ \\
\hline 0.01 & $21.8 \pm 0.9^{\mathrm{c}}$ & $35.7 \pm 1.1^{\mathrm{b}}$ & $155 \pm 1.1^{\mathrm{b}}$ \\
0.1 & $18.9 \pm 0.6^{\mathrm{d}}$ & $31.2 \pm 0.6^{\mathrm{c}}$ & $137 \pm 0.9^{\mathrm{c}}$ \\
\hline 1 & $15.8 \pm 0.2^{\mathrm{e}}$ & $27.3 \pm 0.9^{\mathrm{d}}$ & $116 \pm 0.6^{\mathrm{d}}$ \\
10 & $11.6 \pm 0.9^{\mathrm{f}}$ & $21.1 . \pm 0.2^{\mathrm{e}}$ & $82 \pm 1.1^{\mathrm{e}}$ \\
\hline
\end{tabular}

Means \pm standard deviation (SD) followed by same letter within rows indicate no significant difference (Duncan's multiple range test, $\mathrm{P}<0.05$ ).

Table 4. Effect of Bacillus sphaericus on fecundity and longevity of the filarial vector Culex quinquefasciatus in the laboratory.

\begin{tabular}{lccc}
$\begin{array}{l}\text { Treatment } \\
(\mathrm{ppm})\end{array}$ & \multicolumn{2}{c}{$\begin{array}{c}\text { Adult longevity } \\
\text { (Ins) }\end{array}$} & Fecundity \\
& Male & Female & \\
Control & $34 \pm 0.2^{\mathrm{a}}$ & $47 \pm 0.2^{\mathrm{a}}$ & $270 \pm 0.6^{\mathrm{a}}$ \\
0.001 & $30.9 \pm 1.5^{\mathrm{ab}}$ & $44.1 \pm 1.9^{\mathrm{ab}}$ & $249 \pm 2.8^{\mathrm{b}}$ \\
\hline 0.01 & $25.8 \pm 1.5^{\mathrm{b}}$ & $38.4 \pm 1.6^{\mathrm{b}}$ & $215 \pm 3.2^{\mathrm{c}}$ \\
0.1 & $18.2 \pm 2.1^{\mathrm{c}}$ & $25.9 \pm 1.1^{\mathrm{c}}$ & $178 \pm 1.9^{\mathrm{d}}$ \\
\hline 1 & $11.8 \pm 0.9^{\mathrm{d}}$ & $14.6 \pm 1.5^{\mathrm{d}}$ & $119 \pm 1.6^{\mathrm{e}}$ \\
10 & $4.7 \pm 1.0^{\mathrm{e}}$ & $7.1 \pm 0.6^{\mathrm{e}}$ & $63 \pm 0.9^{\mathrm{f}}$ \\
\hline
\end{tabular}

Means \pm standard deviation (SD) followed by same letter within rows indicate no significant difference (Duncan's multiple range test, $\mathrm{P}<0.05$ ). 
In the present study, Aedes aegypti showed a slight reduction in mortality when compared with Culex quinquefasciatus after treatment with Bacillus sphaericus (Bs G3-IV). This may be due to its breeding habitats, characterized by high organic matter and oxygen content, which promotes the growth and development of Bacillus sphaericus. A previous study showed Bacillus sphaericus exhibited only a low level of toxicity against fourth instar larvae of Aedes aegypti (Mulla et al., 1984), but the present isolate was more toxic when compared with those in earlier studies. Usually $B$. sphaericus is minimally toxic to A. aegypti because this species either lacks a specific receptor for the binary toxin of $B$. sphaericus or has an extremely low concentration of such receptors (Nielsen-Le Roux \& Charles, 1992), whereas the isolate B. sphaericus (Bs G3-IV) used in the present study was improved with necessary qualities for targeting $A$. aegypti. Production of enhanced mosquitocidal toxin by $B$. sphaericus 2362 and $B$. sphaericus $14 \mathrm{~N} 1$ using whey permeate (WP) under submerged fermentation conditions has resulted in high mosquitocidal activity (El-Bendary et al., 2008). No significant differences have been found in other factors that could affect the activity of $B$. sphaericus, such as the rate of ingestion of the toxins or differ-

Table 5. Effect of Bacillus sphaericus against larval density of mosquito vectors in breeding sites (stagnant water) of Aedes aegypti.

\begin{tabular}{|c|c|c|c|c|c|}
\hline \multirow[t]{3}{*}{ Site no. } & \multicolumn{5}{|c|}{ Larval density (\%) } \\
\hline & \multirow[t]{2}{*}{ Before treatment } & \multicolumn{4}{|c|}{ After treatment } \\
\hline & & $24 \mathrm{~h}$ & $48 \mathrm{~h}$ & $72 \mathrm{~h}$ & $96 \mathrm{~h}$ \\
\hline 1 & 66 & 39 & 26 & 9 & 0 \\
\hline 2 & 90 & 56 & 38 & 16 & 4 \\
\hline 3 & 69 & 40 & 28 & 12 & 1 \\
\hline 4 & 78 & 45 & 30 & 14 & 4 \\
\hline 5 & 96 & 59 & 38 & 16 & 3 \\
\hline 6 & 82 & 51 & 33 & 16 & 6 \\
\hline Total & 481 & 290 & 193 & 83 & 18 \\
\hline Average & 80.16 & 48.33 & 32.16 & 13.83 & 3 \\
\hline \% Reduction & & 39.70 & 59.87 & 82.74 & 96.25 \\
\hline
\end{tabular}

Location, Vadavalli; habitat, stagnant water bodies; species, Aedes aegypti; stage, larvae; size, $0.6 \times 0.7 \mathrm{~m}$ depth, $0.5 \mathrm{~m}$; required quantity, $0.6 \times 0.7 \times 0.5=0.42 \times 0.5=0.21 \mathrm{~L}$; required concentration, $2.450 \times 10=24.50 \mathrm{ppm}$.

Table 6. Effect of Bacillus sphaericus against larval density of mosquito vectors at the breeding sites (sewage water) of Culex quinquefasciatus.

\begin{tabular}{|c|c|c|c|c|c|}
\hline \multirow{3}{*}{ Site no. } & \multicolumn{5}{|c|}{ Larval density (\%) } \\
\hline & \multirow[t]{2}{*}{ Before treatment } & \multicolumn{4}{|c|}{ After treatment } \\
\hline & & $24 \mathrm{~h}$ & $48 \mathrm{~h}$ & $72 \mathrm{~h}$ & $96 \mathrm{~h}$ \\
\hline 1 & 140 & 56 & 22 & 6 & 0 \\
\hline 2 & 126 & 42 & 14 & 2 & 0 \\
\hline 3 & 138 & 51 & 18 & 5 & 0 \\
\hline 4 & 120 & 35 & 12 & 1 & 0 \\
\hline 5 & 134 & 48 & 17 & 4 & 0 \\
\hline 6 & 130 & 43 & 14 & 1 & 0 \\
\hline Total & 788 & 275 & 97 & 19 & 0 \\
\hline Average & 131.33 & 45.83 & 16.16 & 13.16 & 0 \\
\hline \% Reduction & - & 65.1 & 87.6 & 97.5 & 10 \\
\hline
\end{tabular}

Location, Vadavalli; habitat, sewage water bodies; species, Culex quinquefasciatus; stage, larvae; size $0.4 \times 1.7 \mathrm{~m}$; depth, $0.28 \mathrm{~m}$; required quantity, $0.4 \times 1.7 \times 0.28=0.68 \times 0.28=0.19 \mathrm{~L}$; required concentration, $0.288 \times 10=2.88 \mathrm{ppm}$. ences in proteolytic activation, between $C$. quinquefasciatus and $A$. aegypti (Aly et al., 1989). The present findings also agree with those from earlier studies pointing out the high susceptibility of Culex spp. to B. sphaericus (Singer, 1980; Yousten, 1984; Mulla et al., 1986). B. sphaericus has the unique property of being able to control mosquito larvae in water that is rich in organic matter. B. sphaericus is effective against Culex spp., but is less effective against some other mosquito species (Poopathi \& Abidha, 2010).

In the present study, Bacillus sphaericus (Bs G3-IV) reduced larval and pupal longevity and inhibited adult emergence in both species. The life span of emerged adults was also very low when mosquito larvae were treated with Bacillus sphaericus (Bs G3-IV), the reduction being more pronounced in Culex quinquefasciatus and less so in Aedes aegyp$t i$. Aedes aegypti was generally less susceptible to Bacillus sphaericus (Bs G3-IV), but effects on its longevity and fecundity were comparable with those seen in Culex quinquefasciatus. The affected pupae also resulted in a great reduction in fecundity. Adults emerging from treated larvae were morphologically normal but laid fewer eggs. The number of eggs laid by Culex quinquefasciatus was very low compared with Aedes aegypti. Murugan et al. (2002) reported changes in fecundity after treatment with Bti. Combined treatment of Bti with neem and pongamia showed $76 \%$ adult mortality and a reduction in fecundity (Senthil Nathan et al., 2004). Poopathi \& Tyagi (2002) reported a reduction in adult longevity (17\% in males and $27 \%$ in females) in Culex quinquefasciatus after treatment with Bacillus sphaericus (GR strain), which supports the present findings.

This study showed that Bacillus sphaericus (Bs G3-IV) was also effective in a field environment. The percentage of reduction in larval density was observed every $24 \mathrm{~h}$, and was seen to increase as the time after treatment increased. This supports the observation that the bacterial pesticide was not negatively affected by the external environment and exhibits a persistent effect. This pesticide has also been found to be eco-friendly and non-toxic to non-target organisms. Mittal (2003) reported that the mosquitocidal toxins of certain strains of Bacillus sphaericus and Bacillus thuringiensis var israelensis $\mathrm{H}-14$ (Bti) are highly effective against mosquito larvae in their direct breeding sites, even at very low doses, and are also safe to other nontarget organisms. He also stated that the biolarvicide formulations of B. sphaericus are useful in the control of Culex and certain Anopheles spp., such as An. stephensi and An. subpictus, but are not very effective against An. culicifacies. Because Bacillus sphaericus distinctly affects the developmental stages of insects, it also has distinct advantages over synthetic pesticides. The specificity of the B. sphaericus toxin is in part due to differences in the number of target sites to which it binds (Baumann et al., 1991). The binding of the protein toxin to the gastric caecum and posterior midgut has been observed in Culex pipiens (a susceptible species) but not in resistant Aedes aegypti (Mittal, 2003).

\section{References}

ABBOTT W.S., 1925 - A method of computing the effectiveness of an insecticide. - J. Econ. Entomol. 18: 265-267.

ALY C., MULLA M.S., FEDERICI B.A., 1989 - Ingestion, dissolution, and proteolysis of the Bacillus sphaericus toxin by mosquito larvae. - J. Invertebr. Pathol. 53: 12-20.

AMER A., MEHLHORN H., 2006a - Larvicidal effects of various essential oils against Aedes, Anopheles, and Culex larvae (Diptera, Culicidae). - Parasitol. Res. 99: 466-472.

AMER A., MEHLHORN H., 2006b - Repellency effect of forty-one essential oils against Aedes, Anopheles, and Culex mosquitoes. Parasitol. Res. 99: 478-490. 
BAUMANN P., CLARK M.A., BAUMAN L., BROADWELL A.H., 1991. Bacillus sphaericus as a mosquito pathogen: Properties of the organism and its toxins. - Microbiol Rev. 55: 425-36.

BECKER N., PETRIC D., BOASE C., LANE J., ZGOMBA M., DAHL C., et al., 2003 - Mosquitoes and Their Control. Kluwer Academic Press/Plenum Publisher, New York: 498.

BEI H., HAIZHOU L., XIAOMIN H., YAJUN C., ZHENG D., ZHIMING Y., 2007 - Molecular Characterization of a Glucokinase with Broad Hexose Specificity from Bacillus sphaericus Strain C3-41. - Appl. Environ. Microbiol. 73: 3581-3586.

CHARLES J.F., NIELSEN-LEROUX C., DELÉCLUSE A., 1996 - Bacillus sphaericus toxins: molecular biology and mode of action. - Annu. Rev. Entomol. 41:451-472.

DA SILVA PINTO L., GONCALES R.A., CONCEICAO F.R., KNABAH P.F., BORSUK S., CAMPOS V.F., et al., 2012 - Stability, oviposition attraction, and larvicidal activity of binary toxin from Bacillus sphaericus expressed in Escherichia coli. - Appl. Microbiol. Biotechnol. 95:1235-1241.

DAVIDSON E.W., 1983 - Alkaline extraction of toxin from spores of the mosquito pathogen, Bacillus sphaericus strain 1593. - Can. J. Microbiol. 29: 271-275.

EL-BENDARY M.A., MOHARAM M.E., FODA M.S., 2008 - Efficient mosquitocidal toxin production by Bacillus sphaericus using cheese whey permeate under both submerged and solid state fermentations. - J. Invertebr. Pathol. 98: 46-53.

HOSSAIN M.A.M., CHOWDHURY A.Z., AL-MAHIN A., RAHMAN M., RAHIM K.A., 2007 - Larvicidal activity of Bacillus sphaericus Strain SI-1 and its toxins against Culex quinquefasciantus larvae. Bangladesh J. Microbiol. 24: 125-128.

KESSLER S., GUERIN M.P., 2008 - Responses of Anopheles gambiae, Anopheles stephensi, Aedes aegypti, and Culex pipiens mosquitoes (Diptera: Culicidae) to cool and humid refugium conditions. - J. Vect. Ecol. 33: 145-149.

MANONMANI A.M., HOTI S.L., 1999 - Association of the level of mosquito larvicidal activity with the growth \& sporulation in Bacillus sphaericus H-5a5b strains. - Indian J. Med. Res. 109:147-51.

MITTAL P.K., 2003 - Biolarvicides in vector control: Challenges and prospects. - J. Vect. Borne. Dis. 40: 20-32.

MULLA M.S., DARWAZEH H.A., DAVIDSON E.W., DULMAGE H.T., SINGER S.,1984 - Larvicidal activity and field efficacy of Bacillus sphaericus strains against mosquito larvae and their safety to non target organisms. - Mosquitoes News. 44: 336-342.

MULLA M.S., DARWAZEH H.A., ALY C., 1986 - Laboratory and field studies on new formulations of two microbial control agents against mosquitoes. - Bull. Soc. Vect. Ecol. 11: 255-263.

MURUGAN K., THANGAMATHI P., JEYABALAN D., 2002 - Interactive effect of Botanicals and Bacillus thuringiensis Subsp. Israelensis on Culex quinquefasciatus Say. - J. Sci. Ind. Res. 61: 1068-1076.

NIELSEN-LEROUX C., CHARLES J.F., 1992 - Binding of Bacillus sphaericus binary toxin to a specific receptor on midgut brush-border membranes from mosquito larvae. - Euro. J. Biochem. 210: 585-590.

OPOTA 0., GAUTHIER N.C., DOYE A., BERRY C., GOUNON P., LEMICHEZ E., et al., 2011 - Bacillus sphaericus binary toxin elicits host cell autophagy as a response to intoxication. - PLoS ONE 6: e14682.

PEI G., OLIVEIRA C.M.F., YUAN Z., NIELSEN-LEROUX C., SILVA-FILHA M.H., YAN J., REGIS L., 2002 - A strain of Bacillus sphaericus causes slower development of resistance in Culex quinquefasciatus. Appl. Environ. Microbiol. 68: 3003-3009.

POOPATHI S., ABIDHA S., 2010 - Mosquitocidal bacterial toxins
(Bacillus sphaericus and Bacillus thuringiensis serovar israelensis): Mode of action, cytopathological effects and mechanism of resistance. - J. Physiol. Pathophysiol. 1: 22-38.

POOPATHI S., RAMESH N., SUNDARAVADIVELU K., SAMUEL P., TYAGI B.K., 2009 - Larvicidal efficacy of various formulations of Bacillus sphaericus against the resistant strain of Culex quinquefasciatus (Diptera: Culicidae) from southern India. - Trop. Biomed. 26: 23-29.

P0OPATHI S., TYAGI B.K., 2002 - Studies on Bacillus sphaericus toxicity-related resistance development and biology in the filariasis vector, Culex quinquefasciatus (Diptera: Culicidae) from South India. - Appl. Entomol. Zool. 37: 365-371.

PRABHAKARAN G., BALARAMAN K., HOTI S.L., MANONMANI A.M., 2007 - A cost-effective medium for the large-scale production of Bacillus sphaericus $\mathrm{H} 5 \mathrm{a} 5 \mathrm{~b}$ (VCRC B42) for mosquito control. - Biol. Control. 41: 379.

REGIS L., SILVA-FILHA M.H., NIELSEN-LEROUX C., CHARLES J.F., 2001 - Bacteriological larvicides of dipteran disease vectors. - Trends Parasitol. 17: 377-380.

REITER P., 1983 - A portable, battery-powered trap for collecting gravid Culex mosquitoes. - Mosquito News. 43: 496-498.

REITER P., 1987 - A revised version of the CDC gravid mosquito trap. J. Am. Mosq. Control Assoc. 3: 325-327.

ROZENDAAL J.A., 1997 - Vector control: methods for use by individuals and communities. Geneva: World Health Organization. Available from: http:/www.who.int/whopes/resources/vector_rozendaal/en/

SENTHIL NATHAN S., CHUNG P.G., MURUGAN K., 2004 - Effect of botanicals and bacterial toxin on the gut enzyme of Cnaphalaocrocis medinalis. - Phytoparasitica. 32: 433-443.

SINGER S., 1980 - Bacillus sphaericus for the control of mosquitoes. Biotechnol. Bioeng. 22: 1335-1355.

SURENDRAN A., VENNISON S.J., 2011 - Occurrence and distribution of mosquitocidal Bacillus sphaericus in soil. - Acad. J. Entomol. 4: 17-22.

TAUBES G., 2000. Vaccines. Searching for a parasite weak spot. Science 290: 434-437.

WATTANACHAI P., TINTANON B., 1999 - Resistance of Aedes aegypti to chemical compounds in aerosol insecticide products in different areas of Bangkok. Thailand. -Commun. Dis. J. 25: 188-191.

WHO (WORLD HEALTH ORGANIZATION), 1987 - Division of vector biology and control. Geneva: World Health Organization. Available from: http://www.who.int/iris/handle/10665/61608

WHO (WORLD HEALTH ORGANIZATION), 2012 - Defeating malaria in Asia, the Pacific, Americas, Middle East and Europe. Geneva: World Health Organization. Available from: http:/www.who.int/malaria/ publications/atoz/9789241504430/en/index.html

YADAV R.S., SHARMA V.P., UPADHYAY A.K., 1997 - Field trial of Bacillus sphaericus strain B-101 (serotype H5a, 5b) against filariasis and Japanese encephalitis vectors in India. - J. Am. Mosq. Control Assoc. 13: 158-63.

YOUSTEN A.A., 1984 - Bacterophage typing of mosquito pathogenic strains of Bacillus Sphaericus. - J. Invertebr. Pathol. 43: 124-125.

YOUSTEN A.A., DAVIDSON E.W., 1982 - Ultrastructural analysis of spores and parasporal crystals formed by Bacillus Sphaericus 2297. - Appl. Environ. Microbiol. 44: 1449-1455.

ZEBITZ C.P.W., 1984 - Effects of some crude and azadirachtin enriched neem Azadirachita indica seed kernel extracts on larvae of Aedes aegypti. - Entomol. Exp. Appl. 35: 11-14.

ZEBITZ C.P.W., 1986 - Effects of three neem seed kernel extracts and azadirachtin on larvae of different mosquito species. - J. Appl. Entomol. 102: 455-463. 